\title{
PENGGUNAAN MODEL PEMBELAJARAN KOOPERATIF TIPE TALKING STICK \\ PADA MATA PELAJARAN IPS UNTUK MENINGKATKAN HASIL BELAJAR \\ SISWA PADA MATERI AKTIVITAS EKONOMI DAN SUMBER DAYA ALAM DI KELAS IV SDN 8 TONGKUNO KABUPATEN MUNA ${ }^{1}$
}

\author{
USE OF COOPERATIVE LEARNING MODEL TYPE TALKING STICK TYPE \\ ON IPS IPS LEARNING TO IMPROVE LEARNING RESULTS \\ STUDENTS ON ECONOMIC AND RESOURCES ACTIVITIES MATERIALS \\ NATURE IN CLASS IV SDN 8 TONGKUNO MUNA DISTRICT ${ }^{l}$
}

\author{
Wa Ode Arini Maut ${ }^{2}$ \\ email: arinimaut1@gmail.com
}

\section{${ }^{1)}$ Hasil Penelitian Tahun 2019, 2) Guru SD 8 Tongkuno}

\begin{abstract}
ABSTRAK: Masalah pokok penelitian ini adalah apakah penggunaan model pembelajaran kooperatif tipe Talking Stick pada mata pelajaran IPS dapat meningkatkan hasil belajar siswa pada materi aktivitas ekonomi dan potensi sumber daya alam di kelas IV SDN 8 Tongkuno Kabupaten Muna? Tujuan penelitian adalah untuk meningkatkan hasil belajar siswa pada materi aktivitas ekonomi dan potensi sumber daya alam melalui penggunaan model pembelajaran kooperatif tipe Talking Stick pada mata pelajaran IPS di kelas IV SDN 8 Tongkuno Kabupaten Muna. Penelitian ini dilaksanakan di kelas IV SDN 8 Tongkuno Kabupaten Muna pada semester genap Tahun Pelajaran 2018/2019 dengan jumlah siswa 23 orang, yang terdiri dari 10 orang laki-laki dan 13 orang perempuan. Data penelitian ini diperoleh dari tes hasil belajar untuk melihat keberhasilan belajar siswa setelah penerapan model pembelajaran Talking Stick, lembar observasi untuk guru dan siswa untuk melihat kondisi pelaksanaan tindakan. Prosedur penelitian ini terdiri dari: (1) perencanaan, (2) pelaksanaan tindakan, (3) observasi dan evaluasi, dan (4) refleksi. Sumber data penelitian ini adalah guru dan siswa. Jenis data dalam penelitian ini adalah data kuantitatif adalah hasil belajar siswa yang diambil dengan menggunakan tes hasil belajar, dan data kualitatif diambil dari hasil observasi aktivitas guru dan aktivitas siswa. Data hasil penelitian pada siklus I siswa tuntas berjumlah 14 siswa dengan persentase $60,9 \%$ dan siswa tidak tuntas berjumlah 9 siswa dengan persentase $39,1 \%$ dengan nilai rata-rata siswa 70,2. Keberhasilan aktivitas mengajar guru pertemuan pertama sebesar $63,64 \%$ dan pertemuan kedua sebesar $72,73 \%$. Data hasil penelitian pada siklus II siswa tuntas berjumlah 20 siswa dengan persentase $87 \%$ dan siswa tidak tuntas berjumlah 3 siswa dengan persentase 13\% dengan nilai rata-rata siswa 81 . Keberhasilan aktivitas mengajar guru pertemuan pertama sebesar $90,91 \%$ dan pertemuan kedua sebesar $100 \%$.
\end{abstract}

\section{Kata Kunci: Model, Hasil Belajar, Talking Stick}

ABSTRACT: The main problem of this research is whether the use of the Talking Stick type cooperative learning model in social studies subjects can improve student learning outcomes on economic activity material and natural resource potential in class IV SDN 8 Tongkuno Muna Regency? The research objective is to improve student learning outcomes on economic activity material and natural resource potential through the use of a Talking Stick type cooperative learning model in social studies subjects in class IV SDN 8 Tongkuno Muna Regency. This research was conducted in class IV SDN 8 Tongkuno Muna Regency in the even semester of the 2018/2019 Academic Year with a total of 23 students, consisting of 10 men and 13 women. The data of this study were obtained from the learning achievement test to see the success of student learning after the application of the Talking Stick learning model, observation sheets for teachers and students to see the conditions of action implementation. The procedure of this research consists of: (1) planning, (2) implementing actions, (3) observation and evaluation, and (4) reflection. Data sources of this research are teachers and students. The type of data in this study is 
quantitative data is the learning outcomes of students taken using learning outcomes tests, and qualitative data taken from observations of teacher activities and student activities. The results of research in the first cycle of students complete 14 students with a percentage of $60.9 \%$ and 9 students who did not complete the number of students with a percentage of $39.1 \%$ with an average value of 70.2 students. The success of the teaching activities of the first meeting teachers was $63.64 \%$ and the second meeting was $72.73 \%$. The results of the research in the second cycle of students completed 20 students with a percentage of $87 \%$ and students who did not complete numbered 3 students with a percentage of $13 \%$ with an average value of students 81 . The success of teaching activities of the first meeting teacher was $90.91 \%$ and the second meeting was $100 \%$.

\section{Keywords: Model, Learning Outcomes, Talking Stick}

\section{PENDAHULUAN}

Penggunaan metode maupun strategi pembelajaran yang tidak menarik bagi siswa dalam mengikuti pembelajaran akan berpengaruh terhadap keaktifan dan hasil belajar siswa . keberhasilan proses pembelajaran PKn akan terlihat dari keaktifan siswa selama pembelajaran. Siswa aktif selama pembelajaran akan meningkatkan hasil belajar siswa dan menjadi indikator keberhasilan pembelajaran. Salah satu model pembelajaran interaktif yaitu model pembelajaran kooperatif tipe Talking Stick. Penggunaan model mengajar yang tepat merupakan suatu alternatif dalam usaha menumbuhkan rasa senang bagi siswa dalam mengikuti pelajaran sehingga siswa dapat mempelajari IPS terintegrasi dengan rasa senang sehingga mampu membangunkan raksasa (otak) yang sedang tertidur untuk menyerap ilmu pengetahuan yang diberikan oleh guru dan lingkungan belajarnya. Model pembelajaran kooperatif tipe Talking Stick yang diterapkan oleh guru diharapkan dapat berlangsung secara lebih aktif dan efisien. Sebagai upaya meningkatkan hasil belajar IPS kelas IV SDN 8 Tongkuno. Langkah yang dapat ditempuh antara lain dengan memperbaiki kegiatan belajar mengajar yang lebih interaktif misalnya dengan menggunakan model pembelajaran kooperatif tipe Talking Stick.

\section{Pembelajaran IPS di kelas IV SD}

Ilmu Pengetahuan Sosial merupakan bidang studi baru, karena dikenal sejak diberlakukan kurikulum 1975. Dikatakan baru karena cara pandangnya bersifat terpadu, artinya bahwa IPS merupakan perpaduan dari sejumlah mata pelajaran sejarah, geografi, ekonomi, sosiologi, antropologi. Adapun perpaduan ini disebabkan mata pelajaran-mata pelajaran tersebut mempunyai kajian yang sama yaitu manusia (Hidayati, 2010:4)

IPS merupakan integrasi dari berbagai cabang ilmu-ilmu sosial, seperti sosiologi, antropologi budaya, psikologi sosial, sejarah, geografi, ekonomi, ilmu politik, dan sebagainya. Hal ini lebih ditegaskan lagi oleh Saidiharjo (Hidayati, 2010:7) bahwa IPS merupakan hasil kombinasi atau hasil pemfusian atau perpaduan dari sejumlah mata pelajaran seperti: geografi, ekonomi, sejarah, sosiologi, antropologi, politik. Mata pelajaran tersebut mempunyai ciri-ciri yang sama, sehingga dipadukan menjadi satu bidang studi yaitu Ilmu Pengetahuan Sosial (IPS). Dengan demikian jelas bahwa IPS adalah fusi dari disiplin-disiplin ilmu sosial.

IPS dalam kurikulum bertujuan untuk: a) mengajarkan konsep-konsep dasar sosiologi, geografi, ekonomi, sejarah, dan kewarganegaraan, pedagogis, dan psikologis. b) mengembangkan kemampuan berpikir kritis dan kreatif, inquiri, memecahkan masalah, dan keterampilan sosial, c) membangun komitmen dan kesadaran terhadap nilai-nilai sosial dan kemanusiaan, d) meningkatkan kemampuan bekerjasama, dan berkompetisi dalam masyarakat yang majemuk, baik secara nasional maupun global (Hidayati, 2010:24).

\section{Model Pembelajaran Kooperatif}

Pembelajaran kooperatif adalah strategi pembelajaran yang menekankan pada proses kerjasama, dalam satu kelompok yang biasa terdiri dari 3-5 orang siswa untuk mempelajari materi sampai tuntas. Siswa didorong untuk bekerjasama secara maksimal sesuai dengan keadaan 
kelompoknya. Kerjasama di sini dimaksudkan setiap anggota kelompok harus saling bantu. Yang cepat harus membantu yang lamban, karena penilaian akhir ditentukan oleh penilaian kelompok. Kegagalan individu adalah kegagalan kelompok, dan sebaliknya keberhasilan individu adalah keberhasilan kelompok. Oleh sebab itu, setiap anggota kelompok harus memiliki tanggung jawab yang penuh terhadap kelompoknya (Sanjaya, 2005:106).

Nur (2000:2) menyatakan bahwa unsur-unsur dalam pembelajaran kooperatif adalah sebagai berikut: 1) para siswa harus memiliki persepsi bahwa mereka "tenggelam atau berenang bersama"; 2) para siswa memiliki tanggung jawab terhadap siswa lain dalam kelompoknya, disamping tanggung jawab terhadap mereka sendiri dalam mempelajari materi yang dihadapi; 3) para siswa harus berpandangan mereka semuanya memiliki tujuan yang sama; 4) para siswa harus memberi tugas dan berbagi tanggung jawab sama besarnya diantara para anggota kelompok; 5) para siswa akan diberikan satu evaluasi atau pengahrgaan yang ikut berpengaruh pada evaluasi seluruh anggota kelompok; 6) para siswa berbagi kepemimpinan sementara mereka memperoleh keterampilan bekerja sama, selama belajar; 7) para siswa akan diminta mempertanggungjawabkan secara individual materi yang ditangani dalam kelompok kooperatif.

Tahap pembelajaran kooperatif yang menjadi langkah model pembelajaran kooperatif dirangkum pada tabel berikut :

Tabel. Langkah-langkah Model Pembelajaran Kooperatif

\begin{tabular}{|l|l|}
\hline \multicolumn{1}{|c|}{ Fase } & \multicolumn{1}{|c|}{ Tingkah Laku Guru } \\
\hline $\begin{array}{l}\text { fase-1 } \\
\text { menyampaikan tujuan dan } \\
\text { motivasi pada siswa. }\end{array}$ & $\begin{array}{l}\text { guru menyampaikan semua tujuan pembelajaran yang } \\
\text { ingin dicapai pada pembelajaran tersebut dan } \\
\text { memotivasi siswa belajar. }\end{array}$ \\
\hline $\begin{array}{l}\text { fase-2 } \\
\text { menyajikan informasi }\end{array}$ & $\begin{array}{l}\text { guru menyajikan informasi kepada siswa dengan jalan } \\
\text { demonstrasi hewat bahan bacaan }\end{array}$ \\
\hline $\begin{array}{l}\text { fase-3 } \\
\text { mengorganisasikan siswa ke } \\
\text { dalam kelompok-kelompok } \\
\text { belajar }\end{array}$ & $\begin{array}{l}\text { guru menjelaskan mengenai cara membentuk } \\
\text { kelompok belajar dan membantu setiap kelompok agar } \\
\text { melakukan transisi secara efisien }\end{array}$ \\
\hline $\begin{array}{l}\text { fase-4 } \\
\text { membimbing kelompok } \\
\text { bekerja dan belajar }\end{array}$ & $\begin{array}{l}\text { guru membimbing kelompok-kelompok belajar pada } \\
\text { saat mereka mengerjakan tugas mereka. }\end{array}$ \\
\hline $\begin{array}{l}\text { fase-5 } \\
\text { evaluasi }\end{array}$ & $\begin{array}{l}\text { guru mengevaluasi hasil belajar tentang materi yang } \\
\text { telah dipelajari atau masing-masing kelompok } \\
\text { mempresentasekan hasil kerjanya. }\end{array}$ \\
\hline $\begin{array}{l}\text { fase-6 } \\
\text { memberikan penghargaan }\end{array}$ & $\begin{array}{l}\text { guru mencari cara-cara untuk menghargai baik upaya } \\
\text { maupun hasil belajar individu dan kelompok }\end{array}$ \\
\hline
\end{tabular}

Sumber: Marpaung, (2002:14)

\section{Model Pembelajaran Kooperatif Tipe Talking Stick}

Adapun langkah-langkah pembelajaran Talking Stick adalah sebagai berikut (Aqib, 2013:26): Guru menyiapkan tongkat, Guru menyampaikan materi pokok yang akan dipelajari, kemudian memberikan kesempatan kepada siswa untuk membaca dan mempelajari materi. Setelah selesai membaca buku dan mempelajarinya, guru mempersilahkan siswa menutup bukunya. Guru mengambil tongkat dan memberikan kepada siswa, setelah itu guru memberikan pertanyaan dan siswa yang memegang tongkat tersebut harus menjawabnya, demikian seterusnya sampai sebagian besar siswa mendapat bagian untuk menjawab setiap pertanyaan dari guru. Guru memberikan kesimpulan. Evaluasi. 


\section{METODE PENELITIAN}

Jenis penelitian adalah Penelitian Tindakan Kelas (PTK). Karateristik yang khas dari penelitian tindakan kelas adalah adanya tindakan-tindakan tertentu untuk memperbaiki proses belajar mengajar di kelas IV SDN 8 Tongkuno Kabupaten Muna. Penelitian tindakan kelas ini dilaksanakan pada pada semester Genap tahun ajaran 2016/2017 yang bertempat di SDN 8 Tongkuno Kabupaten Muna. Adapun subjek penelitian ini adalah guru dan siswa kelas IV SDN 2 Lampeapi Kabupaten Konawe Kepulauansebanyak 23 orang siswa meliputi 10 orang siswa lakilaki dan 13 orang siswa perempuan.

Untuk memberikan pemecahan yang tepat terhadap permasalahan penelitian maka ada beberapa faktor yang akan diteliti yaitu (1) faktor siswa terdiri dari: Aktivitas siswa dalam proses pembelajaran yang dilaksanakan ketika guru menggunakan model pembelajaran interaktif yaitu tipe Talking Stick dalam proses pembelajaran IPS, Dari sisi hasil belajar yang diteliti yaitu peningkatan hasil belajar siswa kelas IV SDN 2 Lampeapi Kabupaten Konawe Kepulauanpada setiap siklus tindakan yang dilakukan oleh guru dalam proses pembelajaran IPS. (2) Faktor guru yakni guru yang diteliti yaitu, kemampuan guru dalam menggunakan model pembelajaran interaktif yaitu tipe Talking Stick dalam proses pembelajaran IPS pada siswa kelas IV SDN 2 Lampeapi Kabupaten Konawe Kepulauan. (3) Hasil Belajar yakni peningkatan hasil belajar siswa kelas IV SDN 2 Lampeapi Kabupaten Konawe Kepulauan pada setiap siklus tindakan yang dilakukan oleh guru dalam proses pembelajaran IPS.

Penelitian ini merupakan Penelitian Tindakan Kelas (PTK) yang melakukan proses pengkajian berdaur atau bersiklus dari berbagai kegiatan. Penelitian tindakan kelas ini dilaksanakan terdiri dari 2 (dua) siklus. Tiap siklus dilaksanakan sesuai indikator yang ingin dicapai setiap faktor yang akan diteliti. Langkah PTK merupakan satu daur atau siklus yang terdiri atas: pertama Perencanaan yakni kegiatan yang dilakukan pada tahap ini adalah: membuat skenario pembelajaran, membuat lembar observasi siswa dan guru untuk melihat bagaimana kondisi belajar mengajar di kelas ketika model pembelajaran interaktif yaitu tipe Talking Stick digunakan. Dan membuat lembaran kerja siswa dan lembaran jawaban, serta lembaran kuis tentang materi peta lingkungan setempat. Kedua Pelaksanaan yakni kegiatan yang dilakukan pada tahap ini adalah melaksanakan skenario pembelajaran, yaitu 2 (dua) kali pertemuan setiap siklus. Ketiga Observasi dan Evaluasi kegiatan pada tahap ini adalah melakukan pengamatan pada saat pelaksanaan tindakan. Hal yang diamati adalah aktivitas guru dan siswa selama pembelajaran berlangsung. Setelah itu dilakukan evaluasi, yaitu untuk melihat keberhasilan pelaksanaan tindakan. Dan keempat adalah Refleksi dimana hasil yang diperoleh setelah pelaksanaan tindakan, observasi dan evaluasi, di diskusikan dan dilihat kelemahan yang ada pada setiap siklus dan akan diperbaiki pada perencanaan siklus berikutnya. Model Pelaksanaan Tindakan Kelas (PTK) Sebagai berikut.

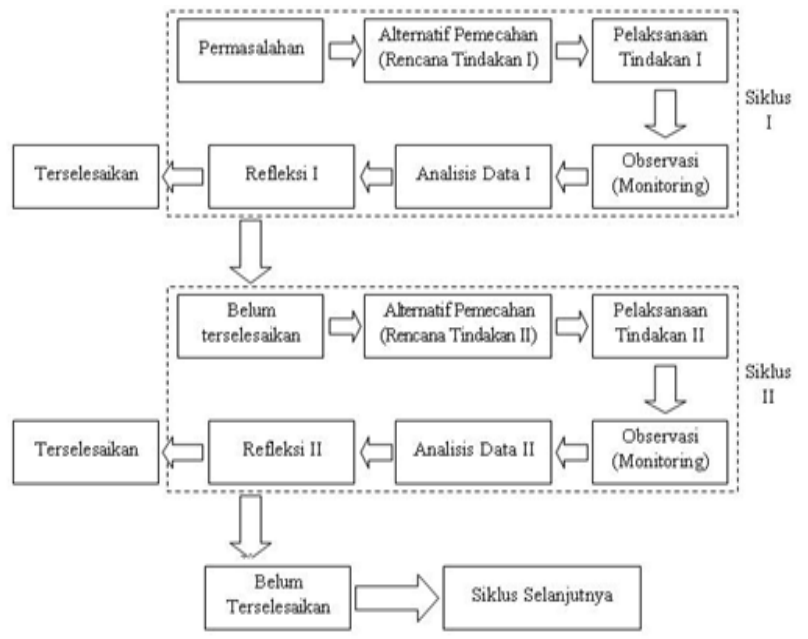

Gambar 3.1. Bagan Alur PTK (Tim Pelatihan Proyek PGSM, 1999:7) 
Sumber data penelitian ini adalah siswa dan guru. Sedangkan jenis data yang digunakan adalah data kuantitatif dan data kualitatif. Data kuantitatif berupa hasil evaluasi belajar siswa. Data kualitatif berupa hasil observasi aktivitas mengajar guru dan aktivitas belajar siswa. Data dikumpulkan dari hasil tindakan yang dilakukan pada kegiatan observasi proses pembelajaran dan tes hasil belajar. Observasi dilakukan untuk memperoleh data tentang kondisi pelaksanaan pembelajaran dengan model pembelajaran interaktif tipe Talking Stick. Tes hasil belajar dilakukan untuk memperoleh data tentang hasil belajar siswa sebagai tolak ukur penguasaan siswa pada materi pembelajaran.

Analisis data dalam penelitian ini adalah menggunakan statistik deskriptif untuk menghitung keberhasilan aktivitas mengajar guru. Keberhasilan aktivitas belajar siswa, nilai siswa, dan ketuntasan belajar. Keberhasilan aktvitas mengajar guru (KAMG) Keberhasilan aktivitas mengajar guru dihitung berdasarkan jumlah skor perolehan guru dibagi dengan jumlah skor maksimum dikalikan dengan seratus persen. $\% K A M G=\mathrm{x} 100 \%$ (Usman dan Setiawati, 1993: 139) Dimana, JSPG: Jumlah skor perolehan guru dalam proses pembelajaran, JSMG: Jumlah skor maksimum yang mungkin diperoleh guru dalam pembelajaran.

Keberhasilan pembelajaran siswa dihitung berdasarkan skor perolehan siswa dibagi dengan skor maksimum dikalikan dengan seratus persen. \% KABS $=$ x 100\% (Usman dan Setiawati, 1993: 132). Dimana, JSPS: Jumlah skor perolehan siswa dalam mengikuti proses pembelajaran (skenario). JSMS: Jumlah skor maksimum dalam proses pembelajaran (skenario). Nilai siswa ditentukan berdasarkan skor yang diperoleh siswa, sedangkan untuk menentukan ketuntasan individu ketuntasan individu siswa ditentukan berdasarkan nilai yang diperoleh pada setiap siklus. Siswa dikatakan belajar tuntas jika nilai yang diperoleh siswa adalah $\geq 70$ sesuai KKM yang ditetapkan sekolah. Ketuntasan klasikal. Indikator keberhasilan penelitian adalah: hasil belajar siswa dikatakan tuntas apabila minimal $80 \%$ siswa telah memperoleh nilai $\geq 70$. Aktivitas guru dan siswa dikatakan berhasil apabila minimal $80 \%$ pembelajaran terlaksana dengan baik.

\section{HASIL PENELITIAN DAN PEMBAHASAN}

\section{Hasil Penelitian}

Berdasarkan penelitian yang dilaksanakan di SDN 2 Lampeapi khususnya siswa kelas IV SD yang jumlah siswanya 23 orang. Penelitian ini di lakukan untuk mengetahui kelayakan melalui penerapan model pembelajaran Talking Stick dalam meningkatkan hasil belajar IPS. Pelaksanaan tindakan dilaksanakan melalui dua siklus dan alokasi waktu tiap kali pertemuan adalah 2 × 35 menit. Pelaksanaan penelitian ini dilakukan secara kolaborasi dengan guru kelas dan kepala sekolah yang membantu dalam pelaksanaan observasi dan refleksi selama penelitian berlangsung, sehingga penelitian bisa terkontrol sekaligus menjaga kevalidan hasil penelitian.

\section{Siklus Penelitian}

Siklus penelitian ini di laksanakan selama satu siklus.di katakana demikian karena hasil yang di capai sudah mencapai target yang di harapkan.

\section{a. Perencanaan}

Berdasarkan hasil penelitian maka yang menjadi catatan penting untuk dapat dijadikan bahan pertimbangan pada pelaksanaan tindakan kelas pada siklus II ini adalah masih kurangnya penguasaan kelas oleh guru, sehingga sebagian siswa belum mencapai hasil yang diharapkan diakibatkan siswa-siswa tidak fokus pada materi yang sedang di pelajari maupun pada model pembelajaran Talking Stick yang digunakan. Pada tahap ini, tentunya peneliti membuat RPP.

\section{b. Pelaksanaan Tindakan}

Pada siklus ini pertemuan pertama dilaksanakan selama 2x35 menit dengan materi Aktivitas Ekonomi dan Potensi Sumber Daya Alam. Pelaksanaan tindakan dilakukan sesuai dengan rancangan pembelajaran yang sudah dirancang. Adapun langkah-langkah yang dilakukan adalah sebagai berikut: 
1) Kegiatan Awal

Dalam kegiatan ini, yang dilakukan guru adalah memberikan salam, absensi, pengelolaan kelas baik pengelolaan pada kesiapan siswa dalam mengikuti proses kegiatan belajar mengajar maupun pengelolaan pada sarana dan prasarana yang akan digunakan dalam proses pembelajaran. Selanjutnya guru menyampaikan tujuan pelajaran yang ingin dicapai yaitu siswa dapat: menyebutkan 2 jenis hutan jika ditinjau dari fungsinya, menyebutkan 2 jenis hutan jika ditinjau dari jenis pohonnya, menyebutkan 3 jenis hutan berdasarkan iklim dan curah hujan secara horizontal, menyebutkan 4 fungsi hutan, menyebutkan usaha pemerintah untuk menjaga kelestarian hutan. Guru memberikan pertanyaan apersepsi yaitu meminta siswa menyebutkan 2 macam usaha perikanan darat. Namun tidak satupun siswa yang menjawab pertanyaan apersepsi. Guru memotivasi siswa agar serius dalam mengikuti pelajaran. Guru juga menjelaskan tentang langkahlangkah pembelajaran Talking Stick yang akan diterapkan.

2) Kegiatan Inti

Guru menyiapkan media tongkat, dan menyampaikan materi Aktivitas Ekonomi dan Potensi Sumber Daya Alam. Kemudian guru menjelaskan secara singkat tentang materi tersebut serta membagikan kepada setiap siswa lembaran tentang materi yang dipelajari serta meminta siswa untuk membaca dan mempelajarinya. Dalam kegiatan ini tidak ada lagi siswa yang tidak yang sibuk bercerita atau bermain. Mereka mulai terbiasa dengan model pembelajaran Talking Stick, sehingga mereka senantiasa memperhatikan dan membaca lembaran materi yang diberikan oleh guru dengan fokus.

Pada tahap selanjutnya, setelah seluruh siswa selesai membaca, guru meminta siswa menutup lembaran materi tersebut. Guru menyiapkan beberapa pertanyaan yang akan diberikan oleh siswa seta mengambil tongkat yang sudah disediakan, kemudian menjalankan tongkat tersebut sambil menyanyikan sebuah lagu yaitu "Sorak-Sorak Bergembira" yang di mulai dari siswa yang paling depan. Setiap kali lagu terhenti, siswa yang memegang tongkat mendapat pertanyaan dari guru dan siswa harus menjawabnya. Dalam kegiatan ini hampir semua siswa dapat menjawab pertanyaan yang diberikan. Guru selalu mengulangi pertanyaan yang sama agar semua siswa mendapat giliran dan terbiasa dengan soal-soal yang diberikan.

3) Kegiatan Akhir

Setelah sebagian besar siswa mendapat giliran untuk menjawab pertanyaan, guru dan siswa bersama-sama menyimpulkan materi pelajaran. Adapun kesimpulan dari materi yang telah dipelajari yaitu guru mengarahkan siswa menyimpulkan materi pelajaran yaitu fungsi hutan, antara lain: sebagai pencegah banjir dan erosi, sebagai penyimpan dan pengatur air tanah, sebagai pencegah terjadinya tanah longsor, sebagai pemupuk kesuburan tanah. Kemudian siswa diberi soal evaluasi. Pada siklus ini pertemuan kedua dilaksanakan selama 2×35 menit dengan materi Aktivitas Ekonomi dan Potensi Sumber Daya Alam. Pelaksanaan tindakan dilakukan sesuai dengan rancangan pembelajaran yang sudah dirancang. Adapun langkah-langkah yang dilakukan adalah sebagai berikut:

1) Kegiatan Awal

Dalam kegiatan ini, yang dilakukan guru adalah memberikan salam, absensi, pengelolaan kelas baik pengelolaan pada kesiapan siswa dalam mengikuti proses kegiatan belajar mengajar maupun pengelolaan pada sarana dan prasarana yang akan digunakan dalam proses pembelajaran. Selanjutnya guru menyampaikan tujuan pelajaran yang ingin dicapai yaitu siswa dapat: menyebutkan 2 potensi ekonomi di daerah pantai yang dapat dimanfaatkan menyebutkan 2 potensi ekonomi di daerah dataran rendah, menyebutkan 2 potensi ekonomi di daerah dataran tinggi, menyebutkan 2 potensi ekonomi di daerah pegunungan, menjelaskan pengertian pedagang asongan, pedagang eceran, pedagang kaki lima, dan pedagang besar. Guru memberikan pertanyaan apersepsi yaitu meminta siswa menyebutkan 2 macam usaha perikanan darat. Namun tidak satupun siswa yang menjawab pertanyaan apersepsi. Guru memotivasi siswa agar serius dalam mengikuti pelajaran. Guru juga menjelaskan tentang langkah-langkah pembelajaran Talking Stick yang akan diterapkan. 


\section{2) Kegiatan Inti}

Guru menyiapkan media tongkat, dan menyampaikan materi Aktivitas Ekonomi dan Potensi Sumber Daya Alam. Kemudian guru menjelaskan secara singkat tentang materi tersebut serta membagikan kepada setiap siswa lembaran tentang materi yang dipelajari serta meminta siswa untuk membaca dan mempelajarinya. Dalam kegiatan ini tidak ada lagi siswa yang tidak yang sibuk bercerita atau bermain. Mereka mulai terbiasa dengan model pembelajaran Talking Stick, sehingga mereka senantiasa memperhatikan dan membaca lembaran materi yang diberikan oleh guru dengan fokus.

Pada tahap selanjutnya, setelah seluruh siswa selesai membaca, guru meminta siswa menutup lembaran materi tersebut. Guru menyiapkan beberapa pertanyaan yang akan diberikan oleh siswa serta mengambil tongkat yang sudah disediakan, kemudian menjalankan tongkat tersebut sambil menyanyikan sebuah lagu yaitu "Sorak-Sorak Bergembira" yang di mulai dari siswa yang paling depan. Setiap kali lagu terhenti, siswa yang memegang tongkat mendapat pertanyaan dari guru dan siswa harus menjawabnya. Dalam kegiatan ini hampir semua siswa dapat menjawab pertanyaan yang diberikan. Guru selalu mengulangi pertanyaan yang sama agar semua siswa mendapat giliran dan terbiasa dengan soal-soal yang diberikan.

3) Kegiatan Akhir

Setelah sebagian besar siswa mendapat giliran untuk menjawab pertanyaan, guru dan siswa bersama-sama menyimpulkan materi pelajaran. Adapun kesimpulan dari materi yang telah dipelajari yaitu guru mengarahkan siswa menyimpulkan materi pelajaran yaitu potensi ekonomi di daerah pantai, dataran rendah, dataran tinggi, dan pegunungan adalah perikanan pariwisata, perdagangan, jasa, dan pertanian. Kemudian siswa diberi soal evaluasi.

\section{c. Observasi dan Evaluasi}

Dari hasil pengamatan diperoleh bahwa aktivitas mengajar guru pada siklus ini pertemuan pertama pelaksanaan pembelajaran telah terlaksana secara maksimal. Dari 11 indikator aktivitas mengajar guru, yang terlaksana 10 indikator atau 90,91\% sedangkan yang tidak terlaksana 1 indikator atau 9,09\%. Aktivitas guru yang terlaksana antara lain: 1) guru menyampaikan tujuan pembelajaran, 2) guru memberikan pertanyaan apersepsi, 3) guru memotivasi siswa agar serius dalam mengikuti pelajaran, 4) guru memperkenalkkan model pembelajaran Talking Stick, 5) guru menyiapkan tongkat, 6) guru menyampaikan materi , 7) guru memberi kesempatan kepada siswa untuk membaca dan mempelajari materi, 8) guru mengarahkan siswa menjawab pertanyaan dengan menggunakan tongkat, 9) guru mengarahkan siswa untuk menjawab soal-soal evaluasi, dan 10) guru mengarahkan siswa menyimpulkan materi pelajaran. Adapun aktivitas guru yang tidak terlaksana yaitu: 1) guru tidak memberikan kesempatan kepada siswa untuk bertanya.

Sedangkan hasil pengamatan aktivitas mengajar guru pada siklus II pertemuan 2 diperoleh bahwa dari 11 indikator Aktivitas mengajar guru, yang terlaksana juga 11 indikator atau $100 \%$. Aktivitas guru yang terlaksana antara lain: 1) guru menyampaikan tujuan pembelajaran, 2) guru memberikan pertanyaan aperrsepsi, 3) guru memotivasi siswa agar serius dalam mengikuti pelajaran, 4) guru memperkenalkan model pembelajaran Talking Stick, 5) guru menyiapkan tongkat, 6) guru menyampaikan materi, 7) guru memberi kesempatan kepada siswa untuk membaca dan mempelajari materi, 8) guru memberi kesempatan kepada siswa untuk bertanya, 9) guru mengarahkan siswa menjawab pertanyaan dengan menggunakan tongkat, 10) guru mengarahkan siswa untuk menjawab soal-soal evaluasi, dan 11) guru mengarahkan siswa menyimpulkan materi pelajaran.

Setelah dianalisis diperoleh data bahwa jumlah siswa yang tuntas hasil belajarnya adalah 20 siswa dengan persentase sebesar $87 \%$. Sedangkan jumlah siswa yang tidak tuntas hasil belajarnya berjumlah 3 siswa dengan persentase sebesar $13 \%$ dan nilai rata-rata siswa secara klasikal adalah 81.

\section{d. Refleksi}

Berdasarkan kajian dan analisis data terhadap proses pembelajaran mulai dari perencanaan hingga evaluasi terhadap aktivitas pembelajaran yang dilakukan ternyata telah terjadi peningkatan pada pembelajaran. Hal ini terlihat pada tingginya aktivitas siswa dalam mengikuti kegiatan belajar 
yang sedang berlangsung, siswa terlihat sangat antusias mengikuti setiap proses pembelajaran melalui model pembelajaran Talking Stick baik dalam menjawab pertanyaan maupun dalam mengerjakan soal latihan. Sehingga dilihat dari hasil observasi dan hasil evaluasi belajar siswa, telah terjadi peningkatan kualitas pembelajaran dan dapat di simpulkan bahwa pada siklus kedua hasilnya sudah baik. Jadi, penelitian ini tidak dilanjutkan lagi.

\section{Pembahasan}

Penelitian ini di laksanakan dengan dua siklus yang pelaksanaannya terdiri dari empat alur yaitu perencanaan, pelaksanaan, observasi dan evalusi, dan refleksi. Pada tahap perencanaan di Siklus ini merancang RPP, menyiapkan media tongkat, lembaran materi, membuat pertanyaan saat menjalankan tongkat, membuat soal evaluasi dan menyiapkan instrumen pengamatan.

Pada pelaksanaan pembelajaran siklus ini dilaksanakan sesuai dengan rencana pembelajaran yang disusun dengan menerapkan model pembelajaran Talking Stick .Pembelajaran mengalami peningkatan, dan dapat dilihat siswa semakin antusias dalam mengikuti proses pembelajaran dengan model pembelajaran Talking Stick ini, nampak sekali siswa dengan serius membaca lembaran materi yang telah dibagikan dan ketika tongkat dijalankan siswa terlihat senang dan mampu menjawab setiap pertanyaan yang di ajukan dengan baik dan benar. Ketika diberikan soal evaluasi, siswa mengerjakannya dengan baik dan hasilnyapun sangat baik bahkan memuaskan. Persentase ketuntasan pada siklus ini mencapai $87 \%$ dengan nilai rata-rata yang diperoleh adalah 81. Itu artinya penerapan model pembelajaran Talking Stick pada mata pelajaran IPS kelas IV di SDN 8 Tongkuno ini terlaksana sesuai dengan apa yang diharapkan. Untuk lebih jelasnya hasil observasi kegiatan guru dan hasil tes siklus ini dapat dilihat pada gambar berikut:

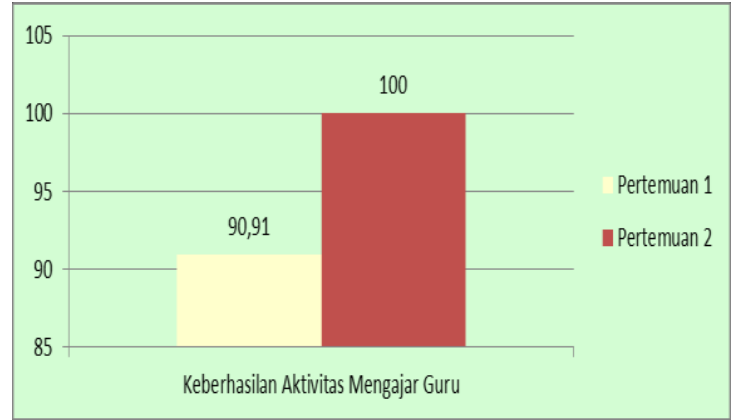

Grafik 4.1 Grafik Observasi Kegiatan Guru

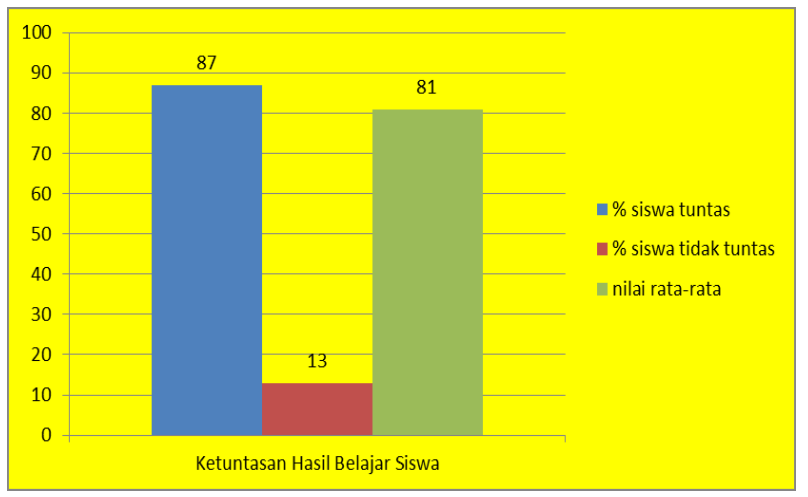

Gambar 4.2 Grafik Persentase dan Nilai Rata-Rata pada Tes 


\section{PENUTUP}

Berdasarkan hasil penelitian dan pembahasan dapat disimpulkan bahwa model pembelajaran Talking Stick merupakan model pembelajaran yang dapat digunakan oleh guru dalam pelaksanaan kegiatan belajar mengajar untuk meningkatkan hasil belajar siswa. Persentase keberhasilan yang dicapai pada siklus ini mencapai $87 \%$ dengan nilai rata-rata 81 .Dengan demikian penelitian ini di hentikan dan telah memenuhi syarat mencapai target yang di harapkan.

\section{DAFTAR PUSTAKA}

Abdurrahman, M. 2003. Pendidikan Bagi Anak Berkesulitan Belajar. Rineka Cipta. Jakarta. Aqib, zainal. 2013. Model-Model Media, dan Strategi Pembelajaran Kontekstual (Inovatif). Bandung: Yrama Widya.

Safarina. 2010. Meningkatkan Prestasi Belajar IPS Siswa Kelas V SDN 1 To'bela Malalui Model Pembelajaran Kooperatif Tipe Talking Stick. Universitas Halu Oleo.

Sanjaya Wina, 2008. Perencanaan dan Desain Sistem Pembelajaran. Jakarta: Kencana.

Sudjana. Nana. 2002. Metoda Statistika. Bandung: Tarsito.

Sukmadinata, N.S., 2004. Landasan Psikologi Proses Pendidikan. Remaja Rosdakarya. Bandung. Suparno, Paul. 2008. Riset Tindakan untuk Pendidik. Jakarta: Grasindo.

Usman, M.U. dan Setiawati, L. 1993. Upaya Optimalisasi Kegiatan Belajar Mengajar.Bandung: Remaja Rosdakarya. 